DOI:10.30842/ielcp230690152363

D. G. Pleshak

(St. Peterburg State University)

\title{
REVISING THE GENRE AND THE DATE OF IN HERACLIUM BY GEORGE OF PISIDIA
}

In Heraclium is the earliest extant poem by George of Pisidia. The poem does not contain reference to the date of its composition, nor is any external evidence present. Overall, the main assumption has been that it was written to celebrate Heraclius' ascent to the throne, after his victory in a revolt against the usurper Phocas. The two main datings are late $610-$ early $611 \mathrm{CE}$, or $618 \mathrm{CE}$.

The present study shows discrepancies between the rules for the panegyrical genre, which the poem is usually ascribed to, and its actual content. The main differences are absence of any reference to Heraclius' background and lack of proper treatment of Heraclius as an emperor. The article shows that all these features are present in the majority of survived verse and prose panegyrics to the emperors, whether they are in Greek or in Latin. Moreover, the poem digresses from the rules set out for an imperial panegyric by the Greek rhetorician Menander, whose recommendation George of Pisidia normally follows, as it has been shown in previous studies. Therefore, In Heraclium does not follow panegyrical tradition of the Late Antiquity.

The article shows that In Heraclium is closer in its content and

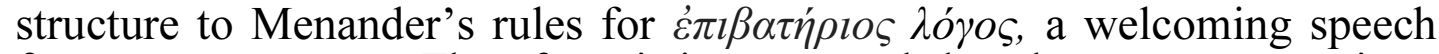
for a new governor. Therefore, it is suggested that the poem was written according to this model and treats Heraclius as an official of non-imperial rank and for this reason he is never portrayed as a supreme ruler. This image fits historical circumstances of Heraclius' raise to power. During his revolt Heraclius did not have claims for the throne and reportedly refused to be crowned as an emperor. Therefore, the poem must have been presented between his capture of the city on the 3 October 610 and his crowning two days later.

Keywords: Byzantine poetry; George of Pisidia; Heraclius.

Д. Г. Плешак

(Санкт-Петербургский гос. университет)

\section{Пересмотр жанра и даты написания поэмы Георгия Писиды «К Ираклию»}

Статья анализирует жанровые особенности поэмы Георгия Писиды «К Ираклию» и уточняет трактовку образа адресата. Выдвигается предположение, что поэма была написана по случаю свержения Фоки Ираклием, но до его коронации.

Ключевые слова: Византийская поэзия; Георгий Писида; Ираклий. 
In early October $610 \mathrm{CE}$, Constantinople was in disarray. The young general Heraclius, the son of the exarch of Africa, led a fleet of military ships from Africa and took the capital on the 3rd of October. The next day the usurper Phocas, who had previously overthrown Maurice and ordered him to be killed, was deposed and decapitated. Phocas' hand was put on a stake and paraded around the Mese. On the 5th, Heraclius was crowned emperor by patriarch Sergius, who immediately conducted a marriage ceremony between the newly proclaimed emperor and his fiancée, Eudokia. These days could possibly be the time when George of Pisidia, the most notable Greek poet of the 7 th century, wrote and presented his first extant poem.

To date, it has been suggested that George of Pisidia's In Heraclium was written as a panegyric for ruling Heraclius some time after his enthronement (Pertusi 1959: 19; Frendo 1984: 177178; Tartaglia 1998: 13-14; Whitby 2002: 159-161; Whitby 2003: 175). This article presents a reevaluation of the poem and suggests that it could have been written and presented as a welcoming piece for Heraclius on his arrival in Constantinople. The structure of the poem digresses significantly from the rules prescribed for panegyrics for the emperor and the main text does not in fact refer to him as a ruler. This might indicate that it should have been written at the moment when Heraclius' status was not yet clear.

\section{The text}

The full title of the poem is On Heraclius the Emperor Who Returned from Africa and Enthroned, and against the emperor

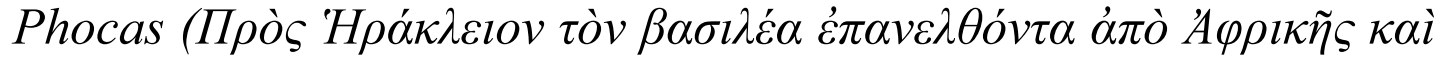

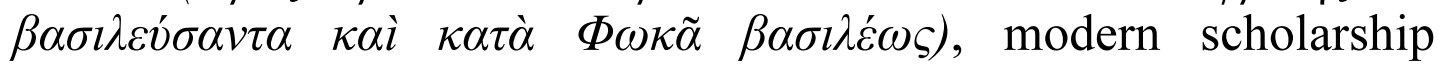
usually referring to it as In Heraclium. The relatively short text comprising 89 lines survived in a single manuscript ${ }^{1}$. There is no external evidence of the date of its composition. The name and contents suggest that it was probably written shortly after Heraclius' takeover. This view was expressed as early as 1891 by the poem's first editor, Leo Sternbach (Sternbach 1891: 34), who placed the poem between Heraclius' takeover and spring 611. The reason for the latter are lines 21-23:

${ }^{1}$ Cod. Paris. Suppl. Gr. 690, 11th century, https://pinakes.irht.cnrs.fr/ notices/cote/53425/. 


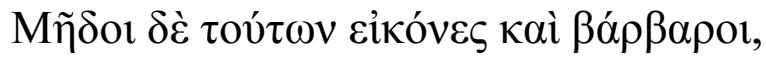

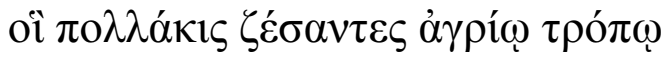

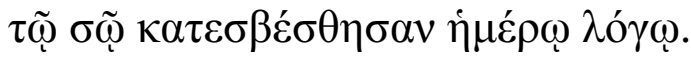

'The Medians and barbarians resembling them (the wild animals pacified by Heraclius' eloquence) raged like wild beasts and were quenched by thine gentle word'.

Sternbach stated that it could not have been written after the Persian campaign in Syria in May 611. Later, Pertusi raised some objections to this position and dated the poem to around 618-9 (Pertusi 1959: 19), during a truce with both Persians and Avars. ${ }^{2}$ Finally, Tartaglia (Tartaglia 1998: 14) gives an additional argument for earlier dating; he notes that the imperfect metre of On Heraclius contrasts with George's later poems and supposes that the poet needed considerable time to improve his versification skills before composing his Expeditio persica in the year 622.

\section{In Heraclium and Menander the Rhetor}

It has been noted that George of Pisidia was under considerable influence of Menander the rhetor (Whitby 1994: 202; Sirotenko 2014; Pleshak 2018). Scholars had mostly focused their attention on comparing George's poems with Menander's treatise $\beta \alpha \sigma l \lambda l \kappa o ̀ \varsigma$ $\lambda o ́$ os (3rd century $\mathrm{CE}$ ), which outlines the rules for composing a panegyric for an emperor. According to Menander, such a text must consist of the following parts (Men. Rh. 368-377):

I Prooimion, in which the author expresses their humility and grandeur of the topic

II The home country or the city of the emperor ( $\pi \alpha \tau \rho i \varsigma)$

III His family ( $\gamma \varepsilon \dot{v} o \varsigma)$

IV His birth ( $\gamma \varepsilon \dot{v} v \sigma l \varsigma)$ and related miracles

V Nurture ( $\left.\alpha v \alpha \tau \rho o \varphi \eta^{\prime}\right)$ and education $(\pi \alpha l \delta \varepsilon i \alpha)$

VI Accomplishments and personal qualities

VII Deeds

VII Wars and trophies

VIII Justice and lawmaking

IX Temperance

$\mathrm{X}$ Wisdom

XI Good fortune

XII Comparison

XIII Epilogue with description of prosperity of the cities

\footnotetext{
${ }^{2}$ For the discussion of both positions cf. (Frendo 1984:167-171).
} 
In Heraclium can be broken down as following ${ }^{3}$ :

1) Impossibility to express Heraclius' grandeur (1-2)

2) Only the narrator can handle this task (3-13)

3) Heraclius' pacificity (13-23)

4) Heraclius' all-concerning intellect and $\varphi \imath \lambda \alpha v \theta \rho \omega \pi i ́ \alpha$ (23-32)

5) Peace brought about by Heraclius (33-38)

6) Phocas' reign of terror (38-51)

7) Heraclius' accomplishments and sacrifice for the common good (51-71)

8) Heraclius' benevolence and expected peace (71-85)

9) Epilogue: the narrator suffers the defeat not being able to reach his goal (86-89)

It can be seen that the first thirteen lines of the poem follow Menander's rules for the prooimion of an imperial encomion ${ }^{4}$. Nevertheless, the following text digresses from the scheme and does not recount Heraclius' family and personal background (II-V of $\beta \alpha \sigma l \lambda l \kappa o ̀ \varsigma \lambda o ́ \gamma o \varsigma)$, but immediately starts discussing his qualities and actions (VI-VII). The only reference to his family is made in the lines 51-52:

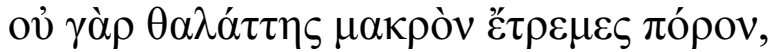

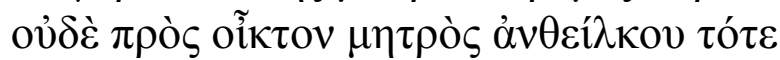

'You did not tremble at a great sea journey, nor were you distracted by mother's love,

According to Menader, the background may be omitted if the addressee is of humble origin (Men. Rh. 370.12-1), but Heraclius in fact came from a very elevated family. His father, Heraclius the Elder, held the position of exarch of Africa prior to the revolt, and during Mauricius' reign he served as a general in the war with Persia $^{6}$. Moreover, such silence is even more suspicious as it was Heraclius the Elder who initiated the revolt against Phocas.

\footnotetext{
${ }^{3}$ Also cf. (Frendo 1984: 171-179).

${ }_{5}^{4}$ On prologues in George of Pisidia cf. (Pleshak 2018).

${ }^{5}$ Phocas imprisoned Heraclius' mother Epiphania in the monastery of Nea Metanoia in Constantinople (Kaegi 2003: 49). The verse may indicate that Heraclius was ready to risk his mother's life by waiting several months before the attack on the city (Pertusi 1959: 82-83).

${ }^{6}$ On the portrayal of this period of his life in Theophylactos see (Whitby 1998: 231-233).
} 


\section{The emperor's background in panegyrics of the Late Antiquity}

In order to understand whether this peculiar digression from the rules is specific only to George of Pisidia, I proceed to compare In Heraclium with other examples of the genre. Greek encomiastic poetry of the Late Antiquity survived in small quantities, so it will be more productive to compare it first with Latin works of the genre.

The first poet to be discussed here is Claudian, whose poem $O n$ the Third Consulate of the Emperor Honorius is similar to On Heraclius in format and size. The poem was performed on $1 \mathrm{st}$ January 396 for the eleven-year-old Honorius, who had been recently crowned emperor after the death of his father (Schindler 2009: 76). Due to Honorius' young age, most parts of the poem do not discuss his own deeds, but instead laud the emperor's family and the acts of his regal ancestors. Similarly, the lines 18-120 of his On the Fourth Consulate of the Emperor Honorius are dedicated to the recipient's $\gamma \varepsilon$ 'vos, while the first hundred lines of On the Fourth Consulate of the Emperor Honorius discuss his childhood on the Palatine and the acts of his father.

Unlike the aforementioned poems, Claudians' On the Consulate of Stilicho was dedicated to a person whose acts had much greater importance than his family. By the time the poem was composed, Stilicho had reached the status of the most powerful person in the empire despite his relatively modest background. Nevertheless, about sixty lines of the poem are dedicated to Stilicho's childhood and ancestors (Schindler 2009: 110-111). Another example of a poem dedicated to a general is Merobaudes' Panegyric to Aetius, who was a Roman general under Valentinianus. This text survived in fragments, but the extant excerpt is dedicated to the younger years and the family of the general (Schindler 2009: 173-6).

Sidonius Apollinaris gives examples of panegyrics to the emperors who did not inherit their power. This Gaulish poet of the late 5th century includes the tropes of yévos and $\pi \alpha l \delta \varepsilon i \alpha$ in his panegyrics to the emperors Maiorianus (lines 107-125), Anthemius (lines 35-207) and Avitus (lines 108-195). It must be noted that these emperors reigned in the last two turbulent decades of the Western Roman empire and none of them inherited power from their predecessors like Honorius, and Maiorianus even gained power as a result of a soldiers' revolt. Therefore, despite their issues with legitimacy and relatively low ranks of their families, Merobaudes still decided to include these topics in his poems, which is in stark contrast with In Heraclium. 
Not all poems dedicate so much space to the emperor's background. For example, Priscian's Laudatio Anastasii provides a meager eight lines which refer to Anastasius' ancestral links to Pompey. It is so brief that Coyne does not see it as a mention of $\gamma \varepsilon$ vo $\varsigma$ and holds that it was a deliberate digression from Menander's prescriptions (Coyne 1988: 10-11). On the other hand, Schindler considers these lines as written in accordance with Menander's ideas (Schindler 2009: 217). Finally, Corippus does not mention any background of the emperor and describes the deeds of his protagonists right away. This can be explained by Corippus' more epic approach and therefore breaks away from the rules set for the encomion (Nissen 1940; Schindler 2009: 227-309).

A concern regarding Greek encomiastic poetry is that we possess only some fragments of poetry (Viljamaa 1968: 34-35), but not a single complete poem addressed to the emperor or a high official. Still, it is evident that the emperor's background was also an expected topic in such compositions. A fragmentary poem spuriously attributed to Pamperius provides some hints. It praises the Athenian official Theagenes and has a section on his yévos (Viljamaa 1968: 202).

Prosaic Greek encomia of Late antiquity are better represented, especially in the works of the Gaza School. Procopius of Gaza's Encomium to Anastasius shows adherence to Menander's rules and subsequently introduces the emperor's $\pi \alpha \tau \rho i \varsigma$ and révo (Procop. Gaz. Enc., 2-3; Westberg 2010: 52-55). In the previous century, Libanius also included an account of Julian's childhood in his encomion (Liban. Orat. XII 19-41). The same topos is also found in Himerius' Propemptic Oration to Proconsul Flavianus (Orat. 12, 18; Penella 2007: 217-220). The final example is not a panegyric, but a $\pi \rho о \sigma \varphi \omega v \eta \tau \iota \kappa o ̀ \varsigma \lambda o ́ \gamma o \varsigma$ (greeting speech) to the emperor Julian written for the occasion when he returned to Antioch in 362 (Ventura 2018: 403). Even in this situation, Libanius does not spare space and recounts Julian's brilliant education and philosophical studies before the enthronement (Liban. Orat XIII, 18-21; Pelizzari 2015: 73).

Therefore, the emperor's background was a highly expected, if not obligatory part of address to the regal person. However, this rule was not consistently applied in speeches to lesser officials. For example, Himerius' aforementioned Orat. 12 is one of the rare speeches where he refers to the home country, family or childhood of the person. 
We cannot say if omitting these topoi could be regarded as a sign of disrespect towards the emperor and his lowering to the rank of a common official, but it is unlikely to have passed unnoticed. If we consider Mary Whitby's suggestion that it must have been In Heraclium that gave a boost to George's career (Whitby 2003: 174), we can presume that the poem was received well and it did not contain any elements that might have troubled Heraclius. Subsequently, no breach of protocol, such as omitting essential topoi, must have occurred. These observations raise doubts if In Heraclium was written and recorded as an encomion for an emperor, or rather for a person or a lower rank.

\section{Heraclius' portrayal and his status during the revolt}

If we consider In Heraclium as an encomion to a state official, and not an emperor, we can see that there are no obvious references to the recipient's imperial status anywhere except for the title of the poem. George praises Heraclius as a person of outstanding personal qualities and as a hero who saved the Empire, but not as a ruler. The only hint at Heraclius' possible authority are the lines 76-79:

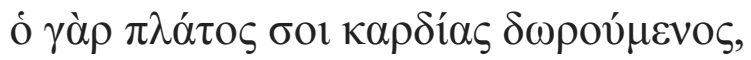

$\dot{\omega} \varsigma \pi \tilde{\alpha} \sigma \mathrm{v} v \dot{\alpha} \rho \kappa \varepsilon i \tilde{\varsigma} \mu \eta \delta \alpha \mu \tilde{\omega} \varsigma \sigma \tau \varepsilon v o u ́ \mu \varepsilon v o \varsigma$,

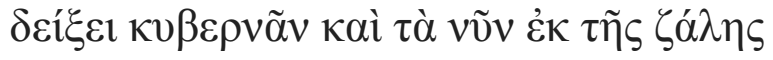

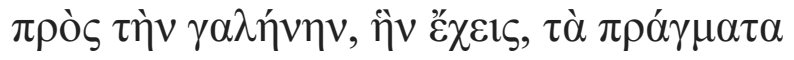

'The breadth of the heart that you were gifted

to enable you to accomplish everything without exhaustion

will show how to lead the affairs from the stormy sea

to the calm haven that you posses'

These rather elusive lines flatter Heraclius and his leading role in the revolt, but not directly name him a ruler. This is in contrast with, for instance, Priscian's treatment of Anastasius (37-39):

Cladibus his tandem caeli rex liberat orbem,

Cum dominum (melius sed patrem diecere possum)

Praebet Anastasium tanta pietate vigintem

'Thus the King of Heavens saved the world from such calamities and gave the title of the lord (but I would better call him the father) to Anastasius, who is full of piety'.

In these extracts both Heraclius and Anastasius come to save the day, but Anastasius is clearly named the lord and the father, while 
Heraclius is a harbinger of change, and praised in this quality ${ }^{7}$. Later, George of Pisidia will not shy away from painting Heraclius as a father figure (Takács 2008: 128-134), but during the composition of this poem he deliberately abstained from it just as he abstained from speaking about Heraclius' family. Even in the much discussed beginning of the poem ${ }^{8}$ ("you are above all things passing") he glorifies Heraclius but does not ascribe him any authority, and the degree of flattery is not superior to, say, Himerius' address to proconsul Cervonius (Himer. Orat. 38.9-10).

Indeed, Heraclius did not style himself as a claimant to the throne during the revolt. Instead, he was leading troops in order to depose a usurper, install legitimate rule and stop political terror (Kaegi 2003: 52). Nor was he the only candidate for the emperorship. Coins minted in the rebelling provinces portrayed him with his father, both bearing the rank of a consul. Heraclius' naval force was supported by a land army led by his cousin Niketas, who could also be seen as a potential emperor (Kaegi 2003: 42-45). This led to a situation where all three persons were confused in the later times, as evidenced by The Armenian History of Sebeos not distinguishing between Heraclius the Elder, his son and Niketas (Kaegi 2003: 46).

The same ambiguity followed Heraclius in Constantinople. According to a range of sources, Heraclius initially refused power and intended to return to his father to Carthage. Reportedly, he first tried to give the crown to the general Priscos, and accepted it himself only after the senate and the people elected him to the throne, but this could also be viewed as an expected sign of the emperor's humility (Kaegi 2003: 50). Regardless, the fate of Heraclius was not certain until the evening of 5 th October 610, and the poem could be expressing this ambiguity of his status.

\section{The genre of the poem}

The situation of early October 610 , i.e. the arrival of a nonimperial figure and coincidental change of power, roughly matches the circumstances that require reading an $\dot{\pi} \pi \imath \alpha \tau \dot{\eta} \rho \imath o \varsigma$ ó $\gamma o \varsigma$. It is supposed to be delivered for a newly appointed governor coming to the city (Menander 381.23-26). The layout is the following (Menander 378-381):

\footnotetext{
${ }^{7}$ Heraclius is also called $\delta \varepsilon \dot{\varepsilon} \sigma \pi \tau \alpha$, but this is usual address to a general. Cf. Procop. Bell. 1.9.8

${ }^{8}$ Cf. Frendo 1984: 171-173.
} 
I) The new governor's arrival causes universal happiness

II) Citizens' misfortune under the old governor

III) Important actions or, if there are none, his origins

VI) Peace brought by him

VII) Virtues

VIII) Wisdom

IX) Comparison with previous governors

$\mathrm{X})$ Epilogue with greetings

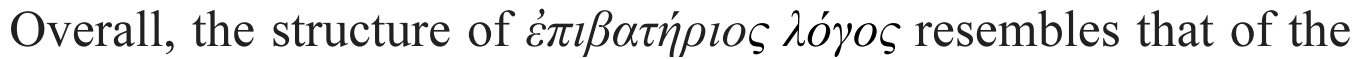
imperial panegyric, but has two main differences. First, mentioning the background of the addressee is optional, and a study by Slootjes shows that it is not present in a number of extant speeches (Slootjes 2006: 113). Menander also strongly recommends the topos of misfortunes under the previous ruler. Both these features are present in In Heraclium along with all other topics required for $\dot{\varepsilon} \pi \imath \alpha \tau \eta \dot{\rho} \rho \imath{ }^{\prime}$ $\lambda o$ yos. Therefore, the poem could have been written with this model in mind. Also, if In Heraclium is a finished work in the genre of

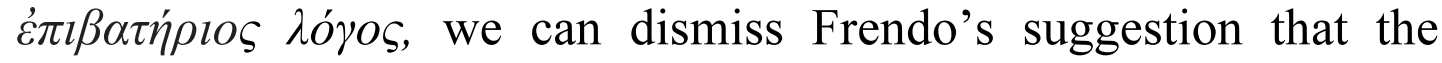
poem is not an independent piece but was composed as a prologue to a large hexametrical poem and later restyled as a separate work.

\section{Conclusion}

Digressions in the form and content of In Heraclium from a typical panegyric for an emperor may suggest that the poem could have been written as a speech on arrival in the time when it was not yet clear that Heraclius would be crowned emperor. This allows one to date the poem between Heraclius' landing on the 3rd October and the crowning ceremony on the $5^{\text {th }}$. It seems even more plausible considering George of Pisidia's improvisation skills (Whitby 2003: 176 n. 18). Alternatively, the poem could have been written in the month before the final assault, when Phocas was losing popularity, and Heraclius was gathering support in his camp on the coast of the Sea of Marmara. The title that suggests the imperial status of Heraclius could have been added later. Nevertheless, this theory does not provide a definite solution to the problem of the lines 5152, as we know nothing of Heraclius' talks with Persians during his rebellion (Kaegi 2003: 41). 


\section{Bibliography}

Claudianus, C. 1922: Claudian, with an English translation by Maurice Platnauer. London: W. Heinemann.

Coyne, P. 1988: Priscian's hymn to Atasthasias. PhD dissertation. Hamilton: McMaster University.

Frendo, J. D. C. 1984: The Poetic Achievement of George of Pisidia. A Literary and Historical Study. In: A. Moffatt (Ed.), Maistor. Classical, Byzantine and Renaissance Studies for Robert Browning. Canberra.

Kaegi, W. 2003: Heraclius, Emperor of Byzantium. Cambridge.

Menander. 1981: Menander Rhetor. Ed. Russel D. A., Wilson N. G. Oxford.

Nissen, Th. 1940: Historisches Epos und Panegyrikos in der Spätantike. Hermes, 75(3), 298-325.

Omissi A. 2018: Emperors and Usurpers in the Later Roman Empire. Civil War, Panegyric, and the Construction of Legitimacy. Oxford: Oxford University Press.

Pantelia, M. C. (Ed.). Thesaurus Linguae Graecae $\bigcirc$ Digital Library. University of California, Irvine. http://www.stephanus.tlg.uci.edu

Pelizzari, A. 2015: Testimonianze di un'amicizia: il carteggio fra Libanio e Giuliano. In: Marcone, A. (ed.). L'imperatore Giuliano: realtà storica e rappresentazione. Milano: Mondadori, 65-86.

Penella, R. J. 2007: Man and the Word. The Orations of Himerius. Berkeley: University of California Press.

Pertusi, A. 1959. Poemi di Giorgio di Pisidia, Panegirici Epici: ed. critica, traduzione e commento a cura di Agostino Pertusi. Ettal: BuchKunstverlag.

Pleshak, D. G. 2018: Prologues in the works by George of Pisidia. Indoevropeiskoe yazykoznanie $i$ klassicheskaya filologiya [IndoEuropean linguistics and classical philology], 22, 1021-1031.

Плешак Д. Г. 2018: Зачины в поэмах Георгия Писиды. Индоевропейское языкознание и классическая филология 22, $1021-1031$.

Schindler, C. 2009: Per carmina laudes: Untersuchungen zur spätantiken Verspanegyrik von Claudian bis Coripp. Beiträge zur Altertumskunde. Berlin, New-York: Walter de Gruyter.

Sidonius. 1936: Ed. W. B. Anderson, Cambridge/Mass.-London.

Sirotenko, A. D. 2014: [Menander and Pisida: on the question of the image of emperor Herclius]. Vizantiyskiy vremennik.

Сиротенко, А. Д. 2014: Менандр и Писида: к вопросу об изображении императора Ираклия. Византийский Временник 73, $62-72$.

Slootjes, D. 2006: The Governor and his Subjects in the Later Roman Empire, History and Archaeology of Classical Antiquity. Leiden; Boston: Brill.

Sternbach, L. 1891: Georgii Pisidiae carmina ineditae. Wiener Studium XIII, 51-68.

Takács, S. 2008. The Construction of Authority in Ancient Rome and Byzantium. The Rhetoric of Empire. Cambridge. 
Tartaglia, L. 1998: Carmi di Giorgio Pisida. A cura di Luigi Tartaglia. Torino.

Ventura, G. 2018. «Is it possible to control the crowd»? Libanius in defense of Julian and against the population of Antioch in the 4th century. Heródoto, Unifesp, Guarulhos, v. 3, n. 1, 394-412.

Viljamaa, K. 1968: Studies in Greek Encomiastic Poetry of the Early Byzantine Period. Commentationes Humanarum Litterarum. Vol. 41.

Westberg, D. 2010: Celebrating with Words: Studies in the Rhetorical Work of the Gaza School. PhD Dissertation. Uppsala.

Whitby, M. 1994: A New Image for a New Age: George of Pisidia on the Emperor. Heraclius. In: Dabrowa, E. (ed.). The Roman and Byzantine Army in the East. Cracow, 197-226

Whitby, M. 2002: George of Pisidia's Presentation of the Emperor Heraclius and his Campaigns: Variety and Development. In: G. J. Reinink, B. H. Stolte (eds.). The reign of Heraclius (610-641): crisis and confrontation. Leuven: Peters.

Whitby, M. 2003: George of Pisidia and the persuasive word: words, words, words... In E. Jeffreys (ed.), Rhetoric in Byzantium. Ashgate, $173-186$.

Whitby, M. 1988: The Emperor Maurice and his Historian: Theophylact Simocatta on Persian and Balkan Warfare. Oxford: Oxford University Press. 